\title{
Article/Artigo
}

\section{Vitamin C effects in mice experimentally infected with Trypanosoma cruzi QM2 strain}

\author{
Efeitos da vitamina $\mathrm{C}$ em camundongos experimentalmente infectados com a cepa QM2 de \\ Trypanosoma cruzi
}

Alex Silva de Gusmão ${ }^{1}$, Roberto Esteves Pires Castanho ${ }^{1}$, Rodrigo Franzoso Almeida de Andrade
Clarisse Moreno Farsetti ${ }^{1}$, Andressa Boim Mathias ${ }^{1}$, Altino Luiz Silva Therezo ${ }^{2}$ and Luciamáre Perinetti Alves Martins ${ }^{1}$

\begin{abstract}
Introduction: To evaluate the efficacy of vitamin $\mathrm{C}$ in reducing the consequences generated by the production of free radicals in the acute and chronic phases of Chagas disease, two different doses of ascorbic acid were administered orally to 60 mice infected by Trypanosoma cruzi QM2 strain. Methods: The animals were divided into six groups: G1, G2, and G3 for the acute phase study, and G'1, G'2, and G'3 for the chronic stage. The groups $G 1$ and G'1 received $8.6 \times 10^{-4} \mathrm{mg} / \mathrm{g}$ of vitamin $\mathrm{C}$ daily, whereas $\mathrm{G} 2$ and $\mathrm{G}^{\prime} 2$ received $7.14 \times 10^{-3} \mathrm{mg} / \mathrm{g}$ daily. The other groups, G3 and G'3, were considered placebos and received $10 \mu \mathrm{L}$ of mineral water. Results: The study of the acute phase showed statistically significant differences between G1 and the other groups at various count days of the parasitemia evolution. The multiplying parasite was slower in G1 until the $11^{\text {th }}$ day, but on the $22^{\text {nd }}$ day it had greater parasitemia than in G2 and G3, and from the $36^{\text {th }}$ day on, parasitemia stabilized at higher levels. However, when the histopathology of acute and chronic phases is considered, one does not note significant differences. Conclusions: The administration of two different doses of vitamin $\mathrm{C}$ was not able to protect mice and to contain the oxidative stress caused by free radicals formed by the metabolism of oxygen (reactive oxygen species) and nitrogen (reactive nitrogen species).

Keywords: Ascorbic acid. T. cruzi. Parasitemia. Free radicals.
\end{abstract}

\section{RESUMO}

Introdução: Para avaliar a eficácia da vitamina $\mathrm{C}$ em reduzir as consequências geradas pela produção de readicais livres na fase aguda e crônica da doença de Chagas, duas diferentes dosagens de ácido ascórbico foram administradas oralmente para 60 camundongos infectados pela cepa QM2 de Trypanosoma cruzi. Métodos: Estes animais foram divididos em seis grupos: G1, G2 e G3 para o estudo da fase aguda e G'1, G'2 e G'3 para o estudo da fase crônica. Diariamente, G1-G'1 recebeu $8.6 \times 10^{-4} \mathrm{mg} / \mathrm{g}$ de vitamina C, G2- G'2 recebeu $7.14 \times 10^{-3} \mathrm{mg} / \mathrm{g}$. Os outros grupos, G3-G'3, foram considerados placebos e receberam $10 \mu \mathrm{L}$ of de água mineral. Resultados: $\mathrm{O}$ estudo da fase aguda mostrou diferenças estatisticamente significativas entre G1 e os outros grupos em vários dias de contagens na evolução da parasitemia, e até o $11^{\circ}$ dia a multiplicação parasitária foi menor em G1, mas no $22^{\circ}$ dia ele tinha parasitemia maior que G2 e G3, e a partir do $36^{\circ}$, a parasitemia estabilizou em altos níveis. Quando considerado o histopatológico da fase aguda e crônica, não foi notado, entretanto, diferença significativa. Conclusões: Assim, foi encontrado que a administração de duas diferentes dosagens de vitamina $C$ não foi capaz de proteger o camundongo e conter o estresse oxidativo causado pelos radicais livres formados pelo metabolismo do oxigênio (ROS) e nitrogênio (RNS).

Palavras-chaves: Acido ascórbico. T. cruzi. Parasitemia. Radicais livres.

\footnotetext{
1. Disciplina de Parasitologia, Faculdade de Medicina de Marília, Marília. SP. 2. Disciplina de Patologia, Faculdade de Medicina de Marília, Marília. SP

Address to: Dra. Luciamáre Perinetti Alves Martins. Rua Dona Maria Feres 165, 17519-070 Marília, SP, Brasil.

Phone: 55 14 3402-1744

e-mail: luciamarepam@gmail.com

Received in 18/02/2011

Accepted in 22/09/2011
}

\section{INTRODUCTION}

According to the World Health Organization ${ }^{1}$, approximately 13 millions individuals are infected by Trypanosoma cruzi in Central and South America, and every year 200,000 new cases are reported. According to the Ministry of Health, there are nearly three million cases in Brazil².

The only drug currently available for the treatment of these patients is benznidazole ${ }^{3}$, the pharmacological action of which results in reactive oxygen species (ROS) formation as superoxide anion and hydrogen peroxide, promoting oxidative damage to T. $\mathrm{cruzi} i^{4-6}$. Besides ROS, reactive nitrogen species (RNS), which are formed from the reaction of nitric oxide (NO) with superoxide radical ${ }^{6,7}$, may also lead to oxidative stress, responsible for many pathological conditions such as chagasic cardiomyopathy ${ }^{8}$.

Trypanosoma cruzi, however, seems to protect itself against the toxicity of free radicals by using ascorbic acid as an antioxidant, as suggested by Wilkinson et al. ${ }^{9}$ and Monteiro et al. ${ }^{10}$. Wilkinson et al. ${ }^{9}$ detected significant levels of ascorbate in epimastigotes of T. cruzi, both in free form and in oxidized form, dehydroascorbate.

To consider new perspectives for the treatment of Chagas disease, Maçao et al. ${ }^{11}$ concluded that the administration of $500 \mathrm{mg} /$ day of vitamin $\mathrm{C}$ and $800 \mathrm{UI} /$ day of vitamin $\mathrm{E}$ for a six-month period was able to halt the progression of oxidative stress in the myocardium of patients at the chronic stage of Chagas disease, because vitamins $\mathrm{C}$ and $\mathrm{E}$ are important sweepers of free radicals ${ }^{12}$.

Based on these studies, one would suppose that interference with the action of free radicals might influence the degree of blood proliferation of T. cruzi as well as the intensity of tissue injury in the target organs of Chagas disease.

As previous studies with vitamin $\mathrm{C}$, free radicals, and T. cruzi were performed in vitro, with 
biochemical parameters or genetic from parasite, we decided to check the levels of parasitemia and the anatomic-pathological features of trypanosomiasis using two different doses of ascorbic acid administered orally to mice infected with T. cruzi QM2 (QuaraíMacarrão 2) strain, lineage IIc (TCIIc), both in the acute and the chronic phases of Chagas disease.

\section{METHODS}

\section{Infection of mice}

Sixty Swiss male mice from 20 days old were weighed to calculate the dosage of vitamin $\mathrm{C}$, and they were intraperitoneally infected with $5.0 \times 10^{4}$ trypomastigotes of T. cruzi QM2 strain $^{13}$, with blood from other mice previously infected. After infection, six groups of 10 mice were established at random, named G1, G2, and G3, and G'1, G'2, and G'3 for the study of the acute and the chronic phases, respectively. The animals were kept in individual cages to facilitate handling.

\section{Calculation of the dosage of vitamin $\mathrm{C}$ and treatment}

To calculate the dosage of vitamin $\mathrm{C}$ to be administered to infected mice, the daily dietary requirement of $60 \mathrm{mg}$ recommended for a man of $70 \mathrm{~kg}$ body weight was considered ${ }^{14,15}$ or approximately $8.6 \times 10^{-4} \mathrm{mg} / \mathrm{g}$ in weight. Vitamin C (ascorbic acid) was used, presented in $200 \mathrm{mg} / \mathrm{ml}$ drops of mineral water for dilution.

G1 and G'1 received a daily dose of vitamin C D60 equal to $8.6 \times 10^{-4} \mathrm{mg}$, diluted in $10 \mu \mathrm{L}$ of mineral water. $\mathrm{G} 2$ and $\mathrm{G}^{\prime} 2$ received a dose D500, corresponding to a daily dosage of $500 \mathrm{mg} /$ day (D500) equal to $7.14 \times 10^{-3} \mathrm{mg}$ of vitamin $\mathrm{C}$ diluted in $10 \mu \mathrm{L}$ of mineral water. G3 and G'3 were considered placebos and received daily $10 \mu \mathrm{L}$ of mineral water.

Every day in the morning, all mice were treated orally and received in their mouth $10 \mu \mathrm{L}$ of vitamin C D60, D500, or mineral water with a Gilson automatic pipette. The mice in groups G1, G2, and $\mathrm{G} 3$ were treated for a period of 45 days to study the acute phase and those in group $G^{\prime} 1, G^{\prime} 2$, and $G^{\prime} 3$ for 180 days to study the chronic phase, starting from the infection date.

This study was approved by the Ethics Committee of the Faculty of Medicine of Marília (FAMEMA) under number 206/08. The care for the maintenance, treatment, and euthanasia of the mice followed the standards set by Colégio Brasileiro de Experimentação Animal/ Brazilian College of Animal Experimentation (COBEA) second Sogayar ${ }^{16}$.

\section{Study of parasitemia}

Blood was collected from the tail following the Brener method ${ }^{17}$, with correction of intermicroscopic field ${ }^{18}$. There was a first count of blood trypomastigotes on the $8^{\text {th }}$ day post-infection, with subsequent assessments until the $43^{\text {rd }}$ day, twice a week.

To analyze the parasitemia, descriptive data analysis and the following tests were used: Kolmogorov-Smirnov, ShapiroWilks, Fisher, and Student $t$ test, with the exclusion criterion, the outliers boxplot prepared group to group for each day of counting. Significance level ( $\alpha$ ) was $5 \%$.

\section{Histopathologic study}

For the histopathologic study a sample from the heart and skeletal muscle from the thigh of all mice were collected, on the $45^{\text {th }}$ day of the study for the acute phase and on the $180^{\text {th }}$ day of the study for the chronic phase. The tissues were embedded in paraffin, and $5 \mu \mathrm{m}$ sections were stained with hematoxylin-eosin and examined under a light microscope with a magnification of 400 times. For each fragment five sequential histological sections were performed, which were analyzed and graded for inflammation process and amastigotes nests, for a total of 10 high-magnification fields for each type of tissue.

We used a semi-quantitative scale from zero to three to grade the inflammatory process and the nests of amastigotes, where the first zero meant the absence of inflammation, one meant mild inflammation, two meant moderate inflammation, and three meant intense inflammation; the second zero meant no amastigote nests, one meant rare nests of amastigotes, two meant a moderate number of nests of amastigotes, and three meant frequent nests of amastigotes.

To analyze the histopathology, descriptive data analysis and the Kruskal-Wallis test (ANOVA non-parametric) with post-test were used. Significance level was 5\%.

\section{RESULTS}

Figure 1 shows the parasitemia curve. All groups showed patent parasitemia on the $8^{\text {th }}$ day post-infection, and on this day G2 had lower parasitemia that was statistically significant compared with G1 (Table 1).

The following counts of blood trypomastigotes showed great variability. Parasitic multiplication in G1 increased more slowly than in the other groups until the peak of parasitemia, which occurred on the $18^{\text {th }}$ day for G2 and G3 and on the $22^{\text {nd }}$ day for G1. Between the $8^{\text {th }}$ day and the $18^{\text {th }}$ day, parasitemia in G1 was lower than that in G2 and G3, with statistically significant results. Between the $32^{\text {nd }}$ day and $43^{\text {rd }}$ day, G1 parasitemia was statistically significantly greater, stabilizing at higher levels than in the other groups. Between G2 and placebo, no statistically significant difference was observed.

The histopathology of the acute phase showed a higher frequency of parasite nests and moderate to intense inflammation in skeletal muscle compared with cardiac muscle, but the differences were not statistically significant, as observed from non-parametric tests for comparison of medians. The isolated analysis of the heart showed

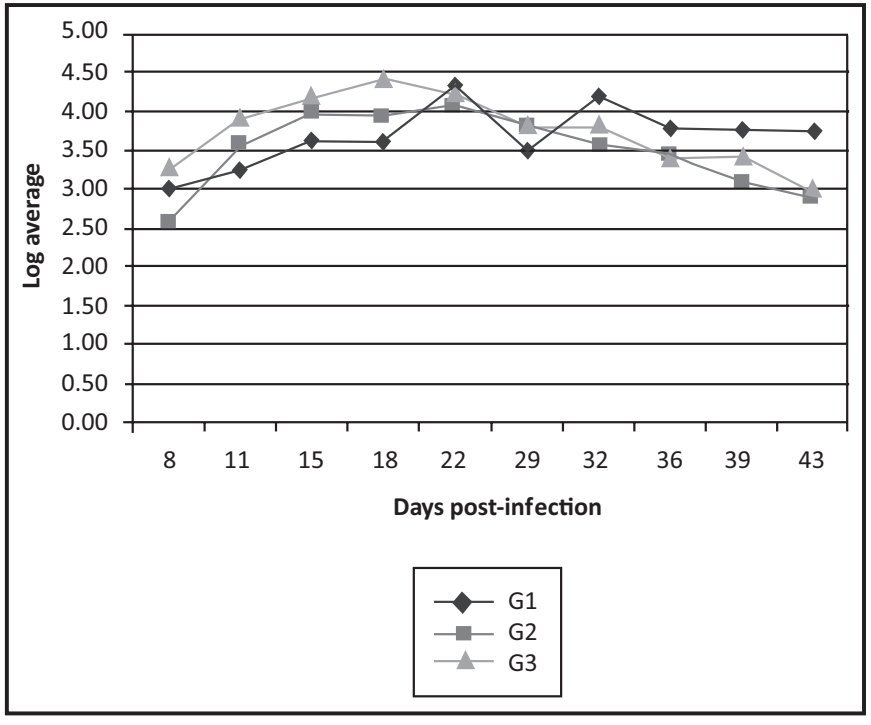

FIGURE 1 - Parasitemic curve of blood tripomastigotas $/ 5 \mu l$ number by $10 g$ mean performed during the acute phase of Trypanosoma cruzi QM2 (QuaraíMacarrão 2) strain infection in mice treated with two different doses of vitamin $\mathrm{C}$ and placebo. 
TABLE 1 - Evolution of parasitemia during the acute phase of Trypanosoma cruzi infection in mice infected with Trypanosoma cruzi QM2 strain and treated with two different doses of vitamin $C$ and placebo.

\begin{tabular}{|c|c|c|c|c|c|}
\hline Days after infection & Group & $\begin{array}{c}\text { Average parasitemia } / 5 \mu \mathrm{L} \\
\text { blood }\end{array}$ & Standard deviation & Compared groups & p-value (\%) \\
\hline \multirow[t]{3}{*}{ Eight (8) } & G1 & 995.45 & $1,173.83$ & G1 \& G2 & $>5.0$ \\
\hline & G2 & 375.16 & 424.19 & G1 \& G3 & 4.8 \\
\hline & G3 & $1,810.95$ & $1,898.29$ & G2 \& G3 & $>5.0$ \\
\hline \multirow[t]{3}{*}{ Eleven (11) } & G1 & $1,782.06$ & $1,733.76$ & G1 \& G2 & 3.5 \\
\hline & G2 & $3,630.31$ & $3,669.11$ & G1 \& G3 & $>5.0$ \\
\hline & G3 & $8,101.64$ & $6,996.39$ & G2 \& G3 & $>5.0$ \\
\hline \multirow[t]{3}{*}{ Fifteen (15) } & G1 & $4,223.07$ & $3,112.36$ & G1 \& G2 & $>5.0$ \\
\hline & G2 & $9,457.59$ & $7,961.51$ & G1 \& G3 & $>5.0$ \\
\hline & G3 & $15,062.41$ & $12,129.64$ & G2 \& G3 & $>5.0$ \\
\hline \multirow[t]{3}{*}{ Eighteen (18) } & G1 & $4,094.27$ & $2,819.40$ & G1 \& G2 & $>5.0$ \\
\hline & G2 & $8,444.28$ & $5,835.92$ & G1 \& G3 & $>5.0$ \\
\hline & G3 & $26,759.63$ & $26,326.31$ & G2 \& G3 & $>5.0$ \\
\hline \multirow[t]{3}{*}{ Twenty-two (22) } & G1 & $21,187.36$ & $18,328.97$ & G1 \& G2 & 3.9 \\
\hline & G2 & $12,036.14$ & $9,122.30$ & G1 \& G3 & 4.3 \\
\hline & G3 & $16,882.90$ & $10,999.47$ & G2 \& G3 & $>5.0$ \\
\hline \multirow[t]{3}{*}{ Twenty-nine (29) } & G1 & $3,328.99$ & $2,658.11$ & G1 \& G2 & $>5.0$ \\
\hline & G2 & $6,425.68$ & $3,835.54$ & G1 \& G3 & 4.8 \\
\hline & G3 & $6,457.87$ & $3,151.77$ & G2 \& G3 & $>5.0$ \\
\hline \multirow[t]{3}{*}{ Thirty-two (32) } & G1 & $15,898.46$ & $15,268.93$ & G1 \& G2 & 3.5 \\
\hline & G2 & $3,761.57$ & $3,741.75$ & G1 \& G3 & $>5.0$ \\
\hline & G3 & $6,293.62$ & $3,913.86$ & G2 \& G3 & $>5.0$ \\
\hline \multirow[t]{3}{*}{ Thirty-six (36) } & G1 & $6,139.33$ & $5,334.10$ & G1 \& G2 & $>5.0$ \\
\hline & G2 & $2,799.03$ & $2,241.90$ & G1 \& G3 & $>5.0$ \\
\hline & G3 & $2,484.22$ & $2,764.70$ & G2 \& G3 & $>5.0$ \\
\hline \multirow[t]{3}{*}{ Thirty-nine (39) } & G1 & $6,211.39$ & $6,170.41$ & G1 \& G2 & $>5.0$ \\
\hline & G2 & $1,182.55$ & 608.13 & G1 \& G3 & $>5.0$ \\
\hline & G3 & $2,719.79$ & $2,411.29$ & G2 \& G3 & $>5.0$ \\
\hline \multirow[t]{3}{*}{ Forty-three (43) } & G1 & $5,382.69$ & $5,032.09$ & G1 \& G2 & 3.9 \\
\hline & G2 & 810.99 & 329.44 & G1 \& G3 & 4.3 \\
\hline & G3 & 931.38 & 569.83 & G2 \& G3 & $>5.0$ \\
\hline
\end{tabular}

QM2: Quaraí-Macarrão 2 strain.

that G1 had fewer parasites compared with G2 and placebo, but no statistically significant difference was observed (Table 2).

In the chronic phase there was a decrease in amastigote nests in both the heart and the skeletal muscle, but the inflammation was less intense in the heart of G2 compared with G1 and placebo.

TABLE 2 - Histopathologic analysis performed in the cardiac muscle and skeletal muscle during acute and chronic experimental chagasic infection by Trypanosoma cruzi QM2 strain in mice treated with two different doses of vitamin $\mathrm{C}$ and placebo.

\begin{tabular}{|c|c|c|c|c|c|}
\hline \multirow[b]{3}{*}{ Phase } & \multirow[b]{3}{*}{ Group } & \multicolumn{3}{|c|}{ Average degree of lesion } & \\
\hline & & \multicolumn{2}{|c|}{ cardiac muscle } & \multicolumn{2}{|c|}{ skeletal muscle } \\
\hline & & $\begin{array}{c}\text { amastigotes } \\
\text { nests }\end{array}$ & $\begin{array}{c}\text { inflammatory } \\
\text { process }\end{array}$ & $\begin{array}{c}\text { amastigotes } \\
\text { nests }\end{array}$ & $\begin{array}{c}\text { inflammatory } \\
\text { process }\end{array}$ \\
\hline \multirow[t]{3}{*}{ Acute } & G1 & 0.40 & 1.40 & 0.80 & 2.30 \\
\hline & G2 & 0.70 & 1.40 & 0.80 & 2.20 \\
\hline & G3 & 0.90 & 1.70 & 0.70 & 2.40 \\
\hline \multirow[t]{3}{*}{ Chronic } & G1' & 0.20 & 0.40 & 0.10 & 0.40 \\
\hline & G2' & 0.00 & 0.10 & 0.10 & 0.50 \\
\hline & G3’ & 0.10 & 0.30 & 0.20 & 0.50 \\
\hline
\end{tabular}

QM2: Quaraí-Macarrão 2 strain.

\section{DISCUSSION}

Vitamin $\mathrm{C}$ or ascorbate is a potent hydrosoluble antioxidant in biological systems in vitro ${ }^{19}$ because it is an electron donor that can directly neutralize $\operatorname{ROS}^{20}$. Depending on the dosage, however, it can also act as a pro-oxidant ${ }^{19,20}$, considering that ascorbate accelerates the glycation end-product formation by connecting the copper protein ascorbylated with free radicals generation by copper-protein complex ${ }^{19}$.

$\mathrm{Maçao}^{7}$ and Ribeiro ${ }^{6}$ showed a decrease in oxidative stress in chronic patients with Chagas disease treated with vitamin $\mathrm{C}$ associated with vitamin $\mathrm{E}$, indicating that the two vitamins act synergistically to prevent peroxidation. Carvalho et al. ${ }^{21}$ showed that vitamin $\mathrm{E}$ deficiency caused exacerbation of sympathetic denervation in mice infected with T. cruzi in the acute phase of illness.

The survey results showed significant differences at times between the two dosages of vitamin $\mathrm{C}$ and placebo, as shown in Table $\mathbf{1}$, although none of the treated groups gained control of parasitemia and the inflammatory process. One should also consider the possible ability of the parasite to possess mechanisms to benefit from the action of ascorbic acid. 
Several studies have demonstrated that T. cruzi can synthesize ascorbic acid from non-enzymatic and enzymatic systems and thereby protect themselves from ROS and $\mathrm{RNS}^{10,22-24}$. According to Wilkinsom et al. ${ }^{23}$ parasites of the Trypanosoma genus may withdraw ascorbate from the culture medium and thus complement the deficiency of biosynthesis.

Jockers-Scherübl et al..$^{25}$, Wilkinsom et al. ${ }^{23}$, Czechowicz et al. ${ }^{26}$, and Ribeiro ${ }^{6}$ reported the presence of one trypanothione reductase dependent on flavoenzyme nicotinamide adenine dinucleotide phosphate; this reductase catalyzes the reduction of trypanothione antioxidant, and this system is able to combat oxidative stress intracellular parasites. Studies by Krieger et al. ${ }^{27}$ showed the possibility of the parasite of this enzyme to enhance its growth and virulence.

Another enzyme, 1-Cys-peroxiredoxins, described by Monteiro et al. ${ }^{10}$, is also used by T. cruzi to synthesize ascorbate; this way, it can decompose peroxides to defend against the action of free radicals.

Although no similar experimental research like ours has been found, the administration of different doses of vitamin $\mathrm{C}$ did not alter the muscle tropism of QM2 strain, as amastigote nests in the heart and skeletal muscle were observed in three groups, but without statistically significant differences in histopathologic analysis. This histopathologic analysis was similar to that found by Martins et al. ${ }^{13}$, who classified this strain in biodemes II after its isolation, according to criteria by Andrade ${ }^{28}$.

Thus, despite the administration of two different doses of vitamin $\mathrm{C}$, the histopathologic findings correlated with parasitemia and showed that the administration of vitamin $\mathrm{C}$ alone was not able to protect mice and was not likely to contain the oxidative stress caused by free radicals formed by the metabolism of oxygen (ROS) and nitrogen (RNS), which was observed by an inflammatory process presence similar in three groups, establishing the characteristic lesions of Chagas disease.

\section{CONFLICT OF INTEREST}

The authors declare that there is no conflict of interest.

\section{FINANCIAL SUPPORT}

Fundação de Amparo à Pesquisa do Estado de São Paulo (FAPESP).

\section{REFERENCES}

1. World Health Organization (WHO). 17 $7^{\text {th }}$ Programme Report (Progress 20032004): Making Health Research Work for Poor People. Tropical Disease Research, Genova; 2005

2. Secretaria de Vigilância em Saúde/Ministério da Saúde (SVS/MS). Guia de Vigilância Epidemiológica. Doença de Chagas. $6^{\text {th }}$ ed., Brasília; 2005.

3. Sociedade Brasileira de Medicina Tropical. Consenso Brasileiro em Doença de Chagas. Rev Soc Bras Med Trop 2005; 38 (supl III): 1-29.

4. Temperton NJ, Wilkinson SR, Meyer DJ, KellyJM. Overexpression of superoxide dismutase in Trypanosoma cruzi results in increased sensitivity to the trypanocidal agents gentain violet and benzonidazole. Mol Bioch Parasitol 1998; 96:167-176.

5. Pedrosa RC, De Bem AF, Locatelli C, Geremias R, Wilhelm Filho D. Timedependent oxidative stress caused by benznidazole. Redox Rep 2001; 6:265-270.

6. Ribeiro CM. Efeito do tratamento do benzonidazol e da terapia antioxidante na cardiopatia chagásica crônica. 111f. Dissertação (Mestrado). Universidade Federal de Santa Catarina, Florianópolis; 2009.
7. Maçao LB. Avaliação do estresse oxidativo na cardiopatia chagásica crônica após terapêutica antioxidante. [Masters Thesis]. [Florianópolis]: Universidade Federal de Santa Catarina; 2006. 93 p.

8. Zacks MA, Wen JJ, Vyatkina G, Bhatia V, Garg N. An overview of chagasic cardiomyopathy: pathogenic importance of oxidative stress. An Acad Bras Ciências 2005; 77:695-715.

9. Wilkinson SR, Obado SO, Mauricio IL, Kelly JM. Trypanosoma cruzi expresses a plant-like ascorbate-dependent hemoperoxidase localized to the endoplasmatic reticulum. Proc Natl Acad Sci 2002; 99:13453-13458.

10. Monteiro G, Horta BB, Pimenta DC, Augusto O, Netto LES. Reduction of 1-Cys peroxiredoxins by ascorbate changes the thiol-specific antioxidant paradigm, revealing another function of vitamin C. Proc Natl Acad Sci 2007; 104:4886-4891.

11. Maçao LB, Wilhelm Filho D, Pedrosa RC, Pereira A, Backes P, Torres MA, et al. Antioxidant therapy attenuates oxidative stress in chronic cardiopathy associated with Chagas' disease. Int J of Cardiol 2007; 123:43-49.

12. Koury JC, Donangelo CM. Zinco, estresse oxidativo e atividade física. Rev Nutr $2003 ; 16: 433-441$.

13. Martins LPA, Marcili A, Castanho REP, Therezo ALS, Oliveira JCP, Suzuki RB, et al. Rural Triatoma rubrovaria from southern Brazil harbors Trypanosoma cruzi of lineage IIc. Am J Trop Med Hyg 2008; 79:427-434.

14. Silva CRM, Naves MMV. Suplementação de Vitaminas na Prevenção de Câncer. Rev Nutr 2001; 14:135-143.

15. Champe PC, Harvey RA, Ferrier DR. Bioquímica Ilustrada. $3^{\text {a }}$ ed. São Paulo: Artmed; 2006.

16. Sogayar R. Ética na experimentação animal: Consciência \& Ação. Botucatu: Fundação de Estudos e Pesquisas Agrícolas e Florestais; 2006.

17. Brener Z. Contribuição ao estudo da terapêutica experimental da doença de Chagas. [Thesis]. [Belo Horizonte]: Universidade Federal de Minas Gerais; $1961.77 \mathrm{p}$

18. Martins LPA. Verificação da susceptibilidade de três espécies de Triatomínae (Hemiptera, Reduviidae) a infecção por duas cepas de Trypanosoma cruzi (Kinetoplastidae, Tripasomatidae) utilizando xenodiagnóstico artificial. [Masters Dissertation]. [Araraquara]: Faculdade de Ciências Farmacêuticas. Universidade Estadual Paulista; 1999.77 p.

19. Padayatty SJ, Katz A, Wang Y, Eck P, Kwon O, Lee JH, et al. Vitamin C as an antioxidant: evolution of its role in disease prevention. J Am Coll Nutr $2003 ; 22: 18-35$.

20. Ferreira ALA, Matsubara LS. Radicais livres: conceitos, doenças relacionadas, sistema de defesa e estresse oxidativo. Rev Ass Med Bras 1997; 43:61-68.

21. Carvalho LSC, Camargos RS, Almeida CE, Peluzio MCG, Alvarez-Leite JL, Chiari E, et al. Vitamin E deficiency enhances pathology in acute Trypanosoma cruzi- infected rats. Trans R Soc Trop Med Hyg 2006; 100:1025-1031.

22. Wilkinson SR, Kelly JM. The role of glutathione peroxidases in Trypanosomatids. Biol Chem 2003; 384:517-525.

23. Wilkinson SR, Prathalingam R, Taylor MC, Horn D, Kelly JM. Vitamin C biosynthesis in trypanosomes: A role for the glycosome. Proc Natl Acad Sci 2005; 102: 11645-11650.

24. Logan FJ, Taylor MC, Wilkinson SR, Kaur H, Kelly JM. The terminal step in vitamin $\mathrm{C}$ biosynthesis in Trypanosoma cruzi is mediated by a FMN-dependent galactonolactone oxidase. J Biochem 2007; 40:419-426.

25. Jockers-Scherübl M, Schirmer H, Krauth-Siegel L. Trypanothione reductase from Trypanosoma cruzi. Eur J Biochem 1989; 180:267-272.

26. Czechowicz JA, Wilhelm AK, Spalding MD, Larson AM, Engel LK, Alberg DG. The synthesis and inhibitory activity of dethiotrypanothione and analogues against trypanothione reductase. J Org Chem 2007; 72:3689-3693.

27. Krieger S, Schwarz W, Ariyanayagam MR, Fairlamb AH, Krauth-Siegel RL, Clayton C. Trypanosomes lacking trypanothione reductase are avirulent and show increased sensitivity to ixidative stress. Mol Microbiol 2000; 35:542-552.

28. Andrade SG. Morphological and behavioural characterization of Trypanosoma cruzi strains. Rev Soc Bras Med Trop 1985; 18 (supl ):39-46. 